\title{
Genetic Diversity Among Three Cultivars of Peanut (Arachis hypogaea L.) Based on RAPD Markers
}

\author{
Suryadi*, Alice Yuniaty, Agus Hery Susanto \\ Faculty of Biologi, Jenderal Soedirman University \\ Jl. dr. Suparno 63 Purwokerto 53122 \\ *Email : suryadi180397@gmail.com
}

Article History :

Received : 22/08/2019

Accepted : 19/10/2019

\begin{abstract}
Arachis hypogea is a typical plant species of tropical regions that has high economic value. The plantation is widely spread over many areas and the production is being pushed to meet the increasing demand. Peanut breeding program is aimed to improve genetic quality, mainly with respect of production and thus information on genetic diversity is necessary as a basis for consideration in breeding, management and sustainable utilization. One approach to analyse genetic diversity of peanut is by using molecular markers. Random Amplified Polymorphic DNA (RAPD) is a widely used molecular marker for genetic diversity analysis. Therefore, the aim of this study was to assess genetic diversity of peanut cultivars, i.e. Jerapah, Kancil, and Hypoma 2, based on RAPD markers. The study was conducted in a survey method, in which three individuals of each cultivar were analyzed using PCR-RAPD technique employing twelve primers, i.e. OPA-1, OPA-2, OPA-9, OPA-13, OPB-2, OPB-3, OPB-4, OPB-5, OPB7, OPB-11, OPB-12 and OPJ-7. Data analysis based on morphological data is also included. Molecular analysis revealed that only $7.55 \%$ polymorphic band was obtained, while most of the bands were monomorphic, indicating very low variation among the cultivars. The phenogram constructed based on literature showed that Kancil was closer to Jerapah cultivar, while RAPD-based dendogram showed that Hypoma 2 was closer to Kancil cultivar.

Keywords: peanut cultivars, genetic diversity, RAPD
\end{abstract}

\section{INTRODUCTION}

Peanut (Arachis hypogea L.) is one of the important oil and protein crops in the world. Breeders around the world have successfully developed hundreds of improved peanut cultivars by making use the diversity in peanut germplasm. The diversity has allowed breeders to better understand the evolutionary relationships among accessions, to sample germplasm in a more systematic fashion, and to develop strategies to incorporate useful diversity in their breeding programs (Al-Saghrir \& Abdel-Salam, 2015).

Scientists have already been doing some approaches that were used to assay genetic diversity in crop plants including morphological traits and isozyme properties. However, these techniques are insufficient to serve as accurate markers due to environmental influences on morphological traits and insufficient polymorphism produced among closely related genotypes. Several PCR based molecular markers have been developed to assist genetic diversity research. Certain properties are desirable for a molecular marker such as highly polymorphic behavior, co-dominant inheritance, frequent occurrence in and even distribution throughout the genome, easy and fast assay and high reproducibility. One of PCR-based DNA molecular markers is random amplified polymorphic DNA (RAPD). RAPD uses a single arbitrary primer to amplify any fragment from the genome complement to the primer. It is considered easy and fast, although lack of reproducibility and it has dominant inheritance (Al-Saghrir \& Abdel-Salam, 2015).

Even though peanut is known to be an important agricultural commodity, genomic and molecular studies have lagged behind those on other legumes such as soybean (Barkley et al., 2007). The lack of polymorphic markers has hindered cultivated peanut, in comparison with other crops, being enhanced by molecular techniques such as marker-assisted selection (MAS) (Barkley et al., 2007). Therefore, exploration on genetic diversity in peanut continues to be the major aspect in many researches. To date, a number of SSR markers have been developed to asses' genetic diversity among peanut accession (Barkley et al., 2007).

RAPD marker depends on the amplification of DNA sequence by polymerase chain reaction with use only a single primer of arbitrary nucleotide sequence. The technique has already proved to be fast and simple, need small quantities of template DNA and able to detect relatively small amounts of genetic variation (Al-Saghrir \& Abdel-Salam, 2015). The objective of this study is to assess the genetic diversity among three peanut cultivars, i.e. Hypoma 2, Kancil, and Jerapah using 
RAPD markers. Diversity in plant genetic resources (PGR) provides opportunity for plant breeders to develop new and improved cultivars with desirable characteristics, which include both farmer-preferred traits (yield potential, seed size etc.) and breeder-preferred traits (pest and disease resistance, photosensitivity).

\section{MATERIALS AND METHODS}

This research project was conducted for sixteen weeks, i.e: January 2019 to April 2019 in Genetic and Molecular Laboratory, the Faculty of Biology, Jenderal Soedirman University. The research has 3 main progress which is DNA extraction from 3 peanut cultivars, quality and quantity testing of the DNA, and RAPD marker amplification. Genomic DNAs were isolated using Geneaid plant DNA kit. The quality of genomic DNA was tested using electrophoresis that used $1 \%$ agarose gel in $1 \mathrm{x}$ TBE buffer. The device was then connected to power supply set at a voltage of $80 \mathrm{~V}$ for 30 minutes. Visualization of DNA bands was performed using a UV transluminator. DNA concentration was measured using UV spectrophotometer at $\lambda 260 \mathrm{~nm}$, while the purity was calculated as the ratio of $260 \mathrm{~nm}$ to $280 \mathrm{~nm}$ absorbance.
PCR was done in a total reaction volume of 12.5 $\mu \mathrm{L}$, consisting of $6,25 \mu \mathrm{L}$ mytag PCR mix, 25 ng DNA template, $1 \mu \mathrm{L}$ primer of $10 \mu \mathrm{M}$, and 5 $\mathrm{mL}$ nuclease-freewater. DNA amplification was performed using PCR machine peqlab primus 250 . Amplification started with pre-denaturation at $95^{\circ}$ $\mathrm{C}$ for 3 minutes, followed by 35 cycles of denaturation at $95^{\circ} \mathrm{C}$ for 15 seconds, annealing at $31 \mathrm{oC}$ for 15 seconds, elongation at $72 \mathrm{oC}$ for 10 seconds and then was terminated with one cycle of final elongation (complete extension) at $72 \mathrm{oC}$ for 5 minutes. The PCR products were visualized using $1.5 \%$ agarose gel electrophoresis technique using 1X TBE buffer. Visualization was performed using a UV transluminator..

The analyses of RAPD bands profile was done by descriptive method. DNA banding pattern that emerges from each individual were used to determine the polymorphism among samples. A band was said to be polymorphic when not all samples had it and a locus is said to be polymorphic if the occurrence of the common allele is more than $95 \%$. The PCR product was scored separately based on its presence or absence in each individual using binary code. A value of 1 was used for the presence and a value of 0 was used for the absence of fragment regardless the intensity.

Tabel 1. PCR primers used

\begin{tabular}{cccc}
\hline No. & Primer & Sequence (5'- 3 ') & Reference \\
\hline 1 & OPA-1 & CAGGCCCTTC & Al-Saghrir \& Abdel-Salam, (2015) \\
2 & OPA-2 & TGCCGAGCTG & Al-Saghrir \& Abdel-Salam, (2015) \\
3 & OPA-9 & GGGTAACGCC & Al-Saghrir \& Abdel-Salam, (2015) \\
4 & OPA-13 & CAGCACCCAC & Al-Saghrir \& Abdel-Salam, (2015) \\
5 & OPB-02 & TGATCCCTGG & Al-Saghrir \& Abdel-Salam, (2015) \\
6 & OPB-03 & CATCCCCCTG & Al-Saghrir \& Abdel-Salam, (2015) \\
7 & OPB-04 & GGACTGGAGT & Al-Saghrir \& Abdel-Salam, (2015) \\
8 & OPB-05 & TGCGCCCTTC & Al-Saghrir \& Abdel-Salam, (2015) \\
9 & OPB-07 & GGTGACGCAG & Al-Saghrir \& Abdel-Salam, (2015) \\
10 & OPB-11 & GTAGACCCGT & Al-Saghrir \& Abdel-Salam, (2015) \\
11 & OPB-12 & CCTTGACGCA & Al-Saghrir \& Abdel-Salam, (2015) \\
12 & OPJ-07 & CCTCTCGACA & Malviya\&Yadav, (2010) \\
\hline
\end{tabular}

\section{Result and Discussion}

1. Genomic DNA Extraction

The results of genomic DNA extraction using GeneAid plant DNA extraction kit are depicted in Figure 1. All the genomic DNAs are seen as clear and single bands, indicating their intactness. Ardiana (2009) noted that DNA of good quality is characterized as thick and clean band when visualized in an electrophoretic gel. Nevertheless, no highly purified DNA is required as PCR template, such as in the case of RAPD marker amplification. 


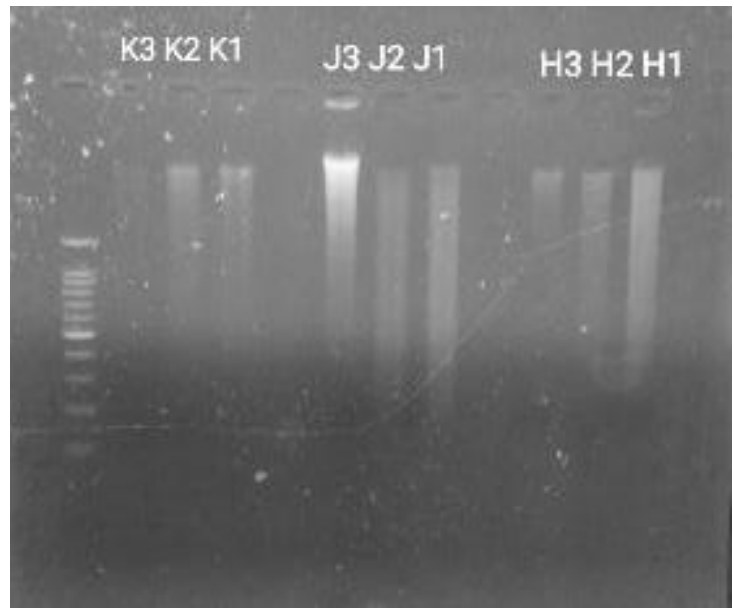

Figure 1. Genomic DNAs of three peanut cultivars $(\mathrm{K}=\mathrm{Kancil}, \mathrm{J}=\mathrm{Jerapah}, \mathrm{H}=\mathrm{Hypoma} 2, \mathrm{M}=100 \mathrm{bp}$ DNA ladder)

2. Measurement of DNA Purity and Concentration

The absorbances of all extracted genomic DNAs at various wavelengths as well as their concentrations and purities are given in Table 2. It is shown in the figure that the purities of the DNAs vary from 1.556 to 1.967 . One DNA sample, i.e:. that of Kancil, showed the 260/280 absorbance ratio of 1.556 , which means that it is contaminated with protein. According to Latif \& Osman (2017), high quality of DNA is characterized by predominantly high molecular weight fragments with an A260/280 ratio ranging between 1.8 and 2.0.

Table 2. DNA Concentration and absorbance ratio of various peanut cultivars

\begin{tabular}{|c|c|c|c|}
\hline Sample & Individual & Concentration $(\mathrm{ng} / \mu \mathrm{L})$ & Á260/Á280 \\
\hline \multirow{3}{*}{ Hypoma 2} & 1 & 19.5 & 1.857 \\
\hline & 2 & 29.5 & 1.967 \\
\hline & 3 & 89 & 1.816 \\
\hline \multirow{3}{*}{ Kancil } & 1 & 69 & 1.792 \\
\hline & 2 & 28.5 & 1.781 \\
\hline & 3 & 31.5 & 1.853 \\
\hline \multirow{3}{*}{ Jerapah } & 1 & 21.5 & 1.955 \\
\hline & 2 & 25.5 & 1.821 \\
\hline & 3 & 35 & 1.556 \\
\hline
\end{tabular}

The concentrations of the DNAs range from 19.5 to $89 \mathrm{ng} / \mu \mathrm{l}$. This means that all the DNAs are in sufficient amount to be used as PCR templates for RAPD marker amplification.

\section{Amplification of RAPD markers}

The number of both monomorphic and polymorphic RAPD bands that are generated from 12 primers could be seen in Table 3 . It is shown that all the 12 random primers successfully produce RAPD bands, indicating that their sequences are compatible with those of unknown amplified loci spread in the genome. Kumari \& Thakur (2014) mentioned that primers attached to the areas that were not specific as coding sequences will result in randomly unknown PCR products. Similarly, Saraswati et al. (2017) stated that random primary amplification such as RAPD occurs in the whole genome, which means that all genetic material will be amplified based on random primer attachments that are not known whether they are genes or not. Then, Latif \& Osman (2017) noted that the assessment of the presence or absence of DNA bands resulting from amplification is sometimes considered very subjective even though the intensity can be quantitatively differentiated based on their molecular weight. 
Table 3. Numbers of RAPD bands generated from 12 primers

\begin{tabular}{ccccc}
\hline Primer & $\begin{array}{c}\text { Total number of } \\
\text { bands }\end{array}$ & Monomorphic band & $\begin{array}{c}\text { Polymorphic band } \\
\text { Polymorphic percentage } \\
(\%)\end{array}$ \\
\hline OPA-1 & 3 & 3 & 0 & 0 \\
OPA-2 & 4 & 4 & 0 & 0 \\
OPA-9 & 6 & 6 & 0 & 0 \\
OPA-13 & 4 & 4 & 0 & 0 \\
OPB-02 & 2 & 2 & 0 & 0 \\
OPB-03 & 7 & 4 & 3 & 0 \\
OPB-04 & 4 & 4 & 0 & 12.5 \\
OPB-05 & 8 & 7 & 1 & 0 \\
OPB-07 & 5 & 5 & 0 & 0 \\
OPB-11 & 5 & 5 & 0 & 0 \\
OPB-12 & 3 & 3 & 0 & 0 \\
OPJ-7 & 5 & 5 & 0 & 7.27 \\
\hline Total & 55 & 49 & 4 & 0 \\
\hline
\end{tabular}

It can be seen from Table 3. that of the selected 12 primers, only two, i.e. OPB-03 and OPB-05, produced polymorphic bands among the three cultivars. The size of the respective band is shown in Figure 3. Primer OPB-3 shows polymorphic bands of 3,000 bp, which are found in Jerapah 2 and 3 (J2 and J3), while no other sample has it. Meanwhile, polymorphic bands result also from OPB 5, where those of 3,000 bp are obtained merely in Jerapah 2 and 3.

Based on Table 3. and Figure 2; the average percentage of polymorphism is $7.55 \%$. This indicates low genetic diversity among cultivars,

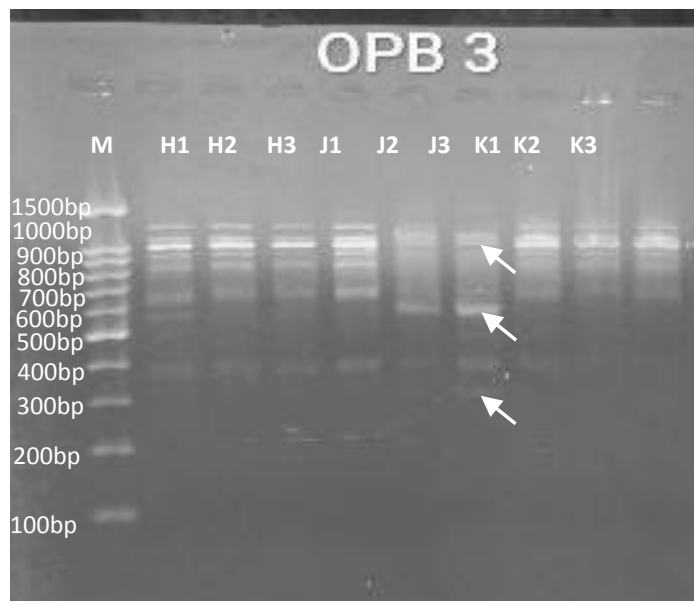

(A) which is probably due to the same genetic background. Low genetic diversity could lead to problem in providing genetic sources in breeding. Low genetic diversity in peanuts is a common thing that indicates all domesticated cultivar originates from the same wild strain. The low genetic diversity can also occur because of the type of autogamy plants (Saraswati, et al., 2017). According to Susanto \& Baskorowati (2018), low genetic diversity in plant requires attention regarding the resistance against environmental factors.

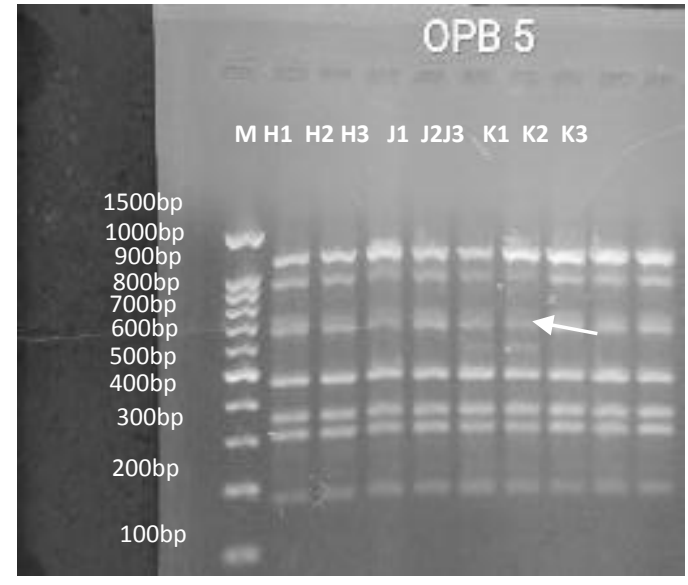

(B)

Figure 2. RAPD markers amplified with OPB-3 and OPB-5. (A) OPB 3 (B) OPB 5. From left to right: DNA ladder, H1, H2, H3, J1, J2, J3, K1, K2, \& K3.

While OPB-3 and OPB-5 result in some polymorphic bands, the other 10 primers produce only monomorphic bands as depicted in Figure 3. Monomorphic DNA bands indicate no genetic variation at all among samples (Naipospos, et al., 2014). Genetic variation in nature can occur due to mutation or recombination, which can be seen from the differences in base sequences. 


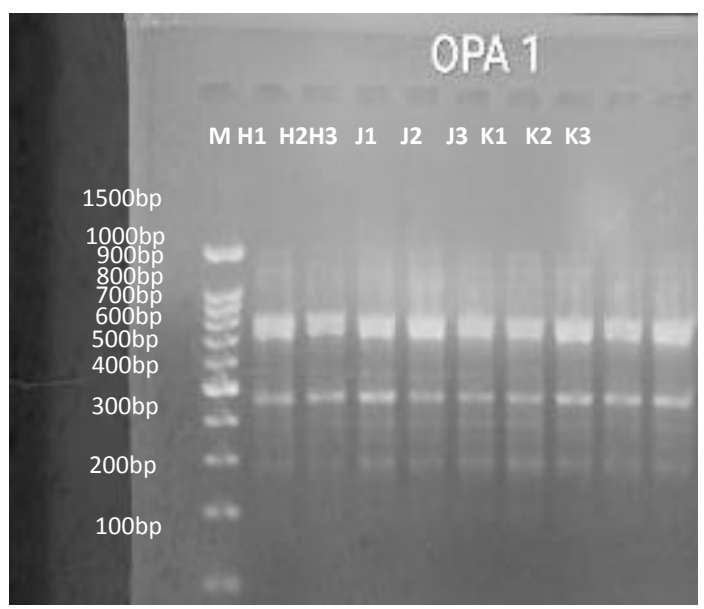

(A)

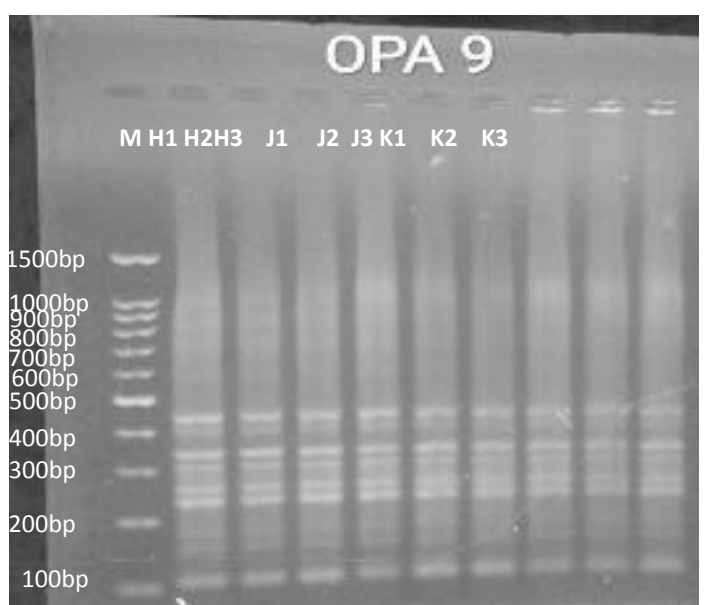

(C)

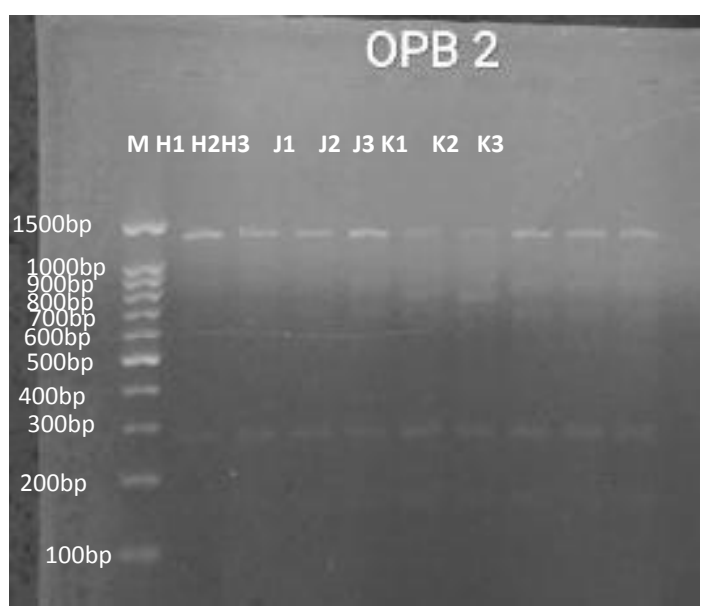

(E)

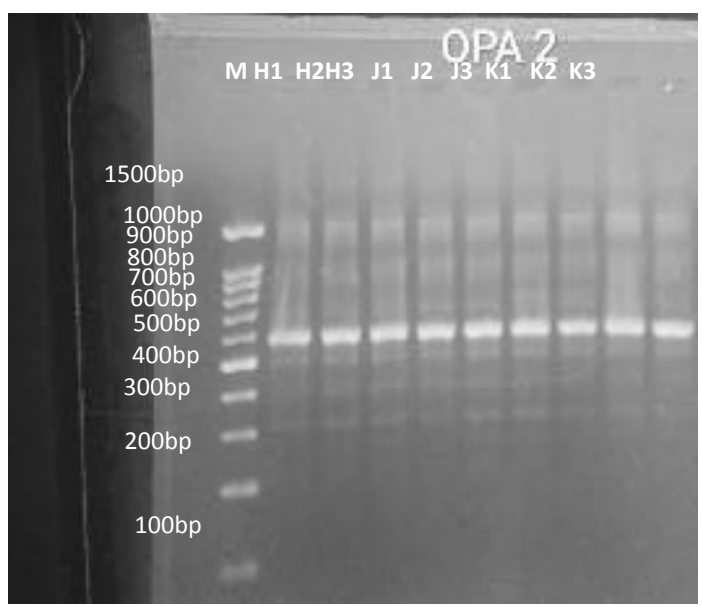

(B)

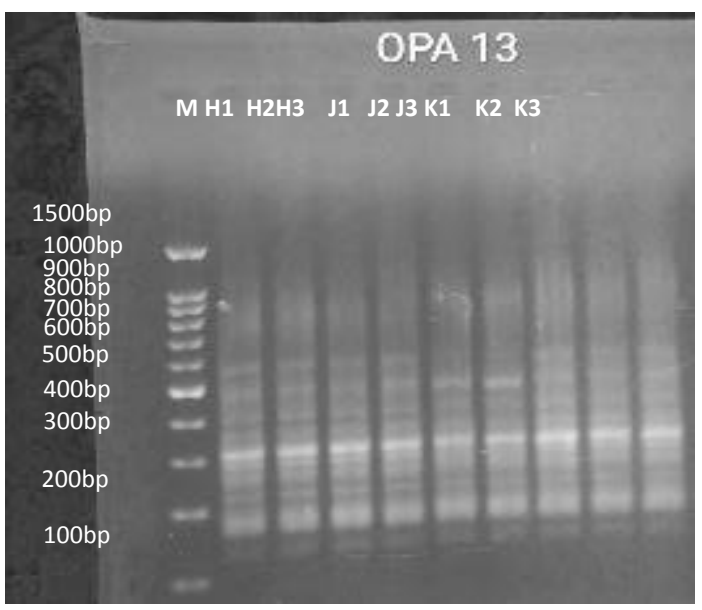

(D)

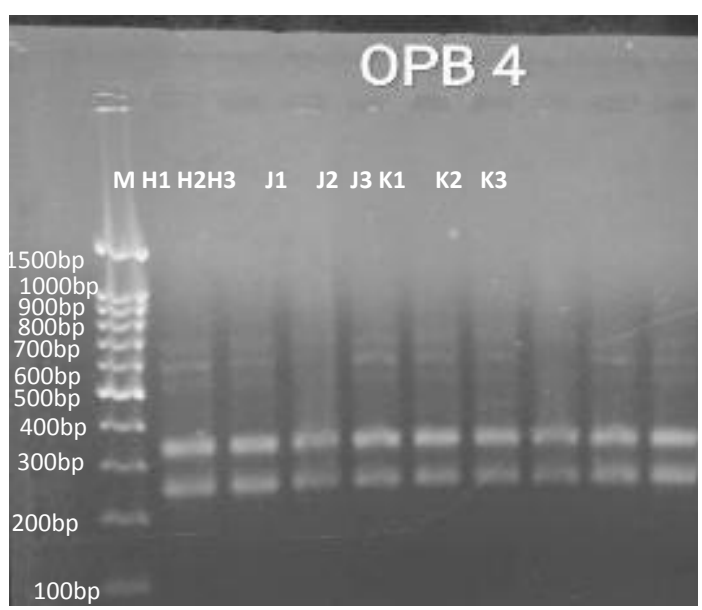

(F) 


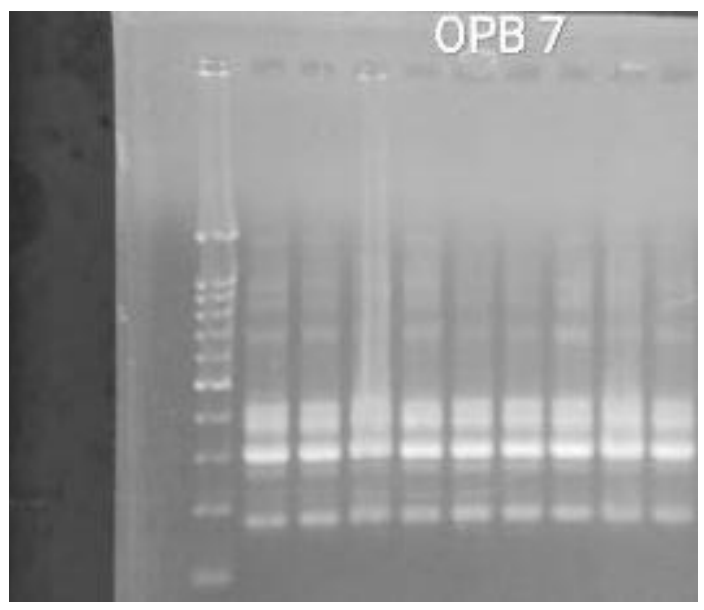

(G)

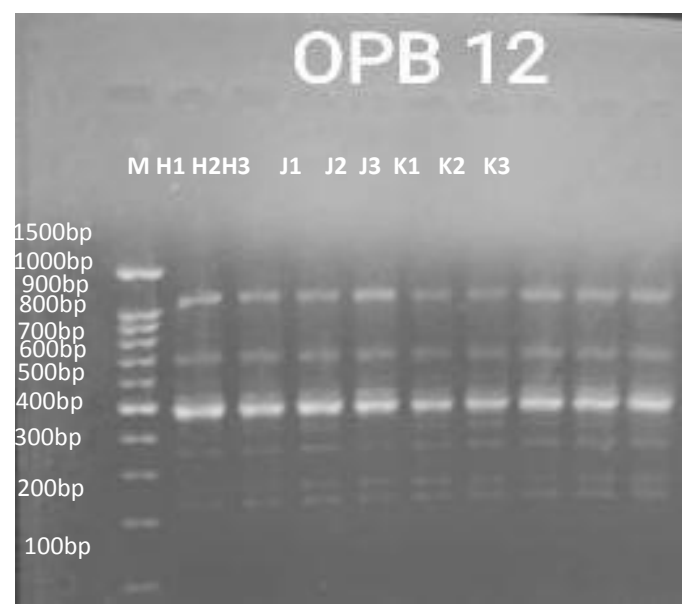

(I)

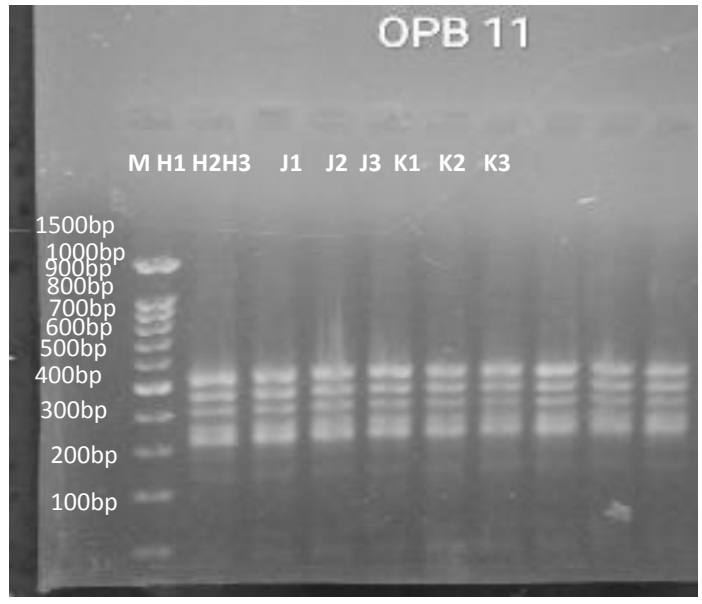

(H)

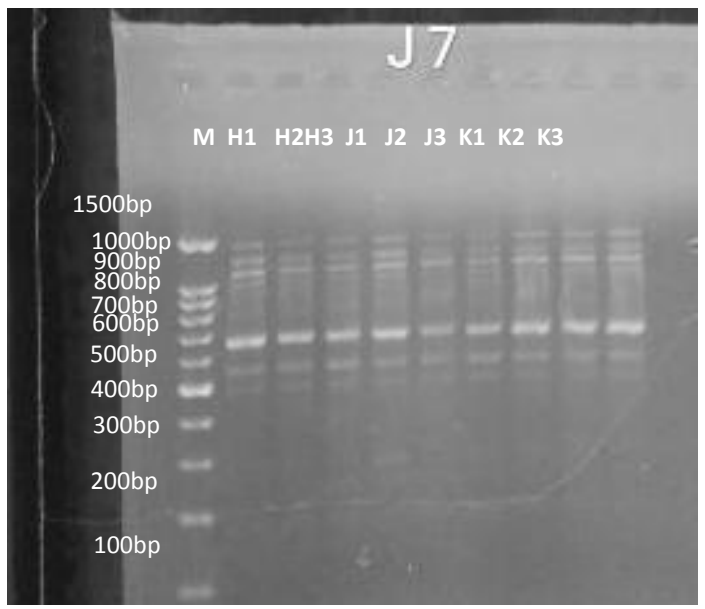

(J)

Figure 3. RAPD markers amplified with OPA-1, OPA-2, OPA-9, OPA-13, OPB-2, OPB-4, OPB-7, OPB-11, OPB12 and J7. (A) OPA-1, (B) OPA-2, (C) OPA-9, (D) OPA-13, (E) OPB-2, (F) OPB-4, (G) OPB-7, (H) OPB-11, (I) OPB-12, (J) J7. From left to right: DNA ladder, H1, H2, H3, J1, J2, J3, K1, K2, \& K3.

Molecular markers have been assisting breeders in crop improvement. Judicious integration of molecular markers with conventional breeding practices has contributed numerous improved varieties. Monomorphic markers are most often eliminated from further investigations assuming that they are not informative. They are still largely being rejected by most of the researchers over countries. There is a need for understanding such so-called "monomorphic markers" (Holla et al., 2014).

The genetic difference among the three peanut cultivars based on RAPD markers, particularly those showing polymorphism, is presented in Figure 4. It is clearly shown that Kancil is genetically closer to Hypoma 2 rather than to Jerapah. 


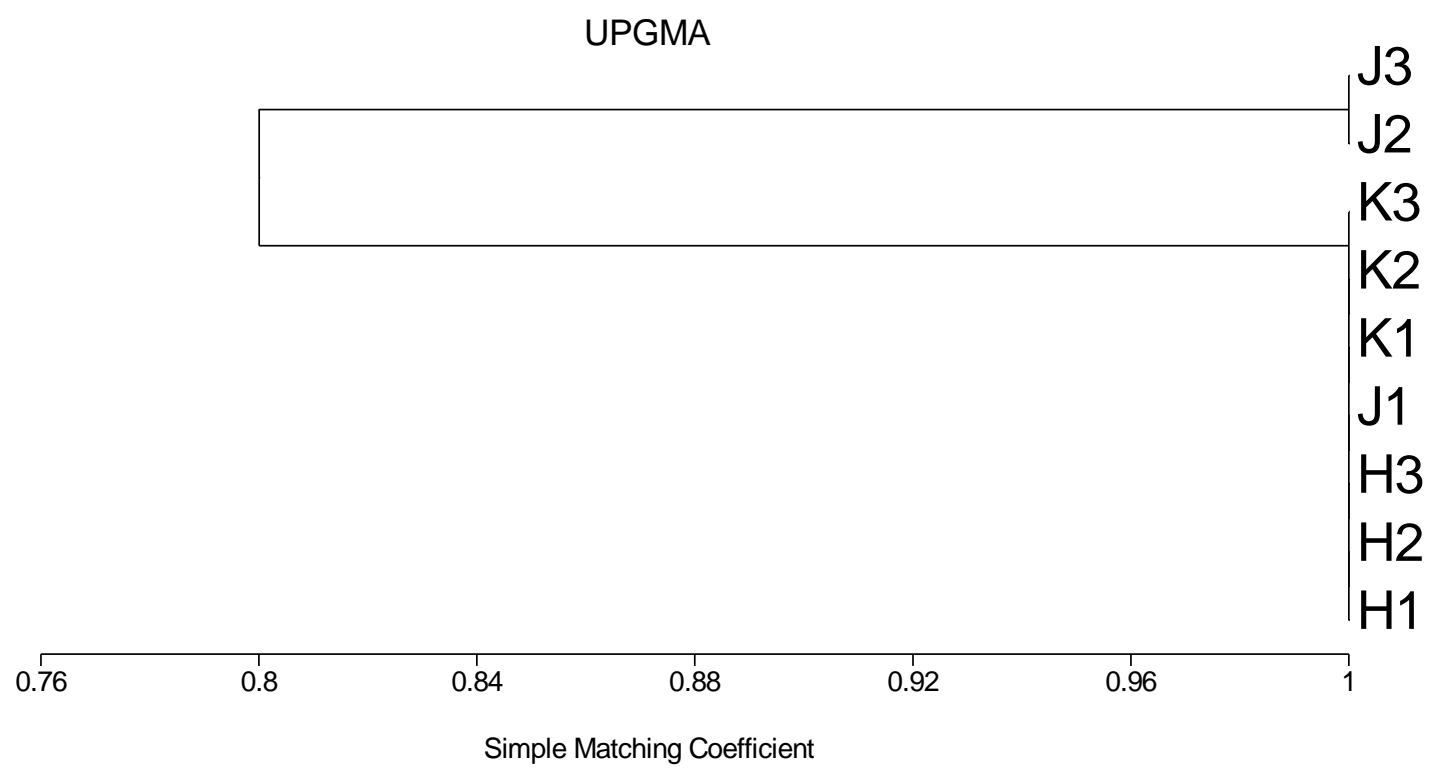

Figure 4. Dendrogram of three peanut cultivars

The genetic diversity among the three peanut cultivars can be compared with their phenotypic variation with respect to morphological characters as presented in Table 4. Based on the characters, a phenogram can be constructed as could be seen in Figure 5. A phenogram is a diagram depicting taxonomic relationships among organisms based on overall similarity of many characteristics regardless the evolutionary history or assumed significance of specific characters. The phenogram, which is based on phenotypical traits is not always congruent, however, with a molecular phylogeny of the group (Agrawal \& Fishben, 2006).

Table 4. Phenetic characteristics of Hypoma 2, Kancil, and Jerapah cultivars*

\begin{tabular}{llll}
\hline Characters & Hypoma 2 & Jerapah & Kancil \\
\hline Age & \pm 90 & \pm 90 & \pm 90 \\
Stem color & Purple greenish & Purple & Green purplish \\
Leaf color & Green & Green & Green \\
Flower color & Wisteria & Wisteria & Yellow \\
Seed color & Rose & Rose & Rose \\
Gynophore color & Purple & Green & Purple \\
Pod shape & Round & Round & Round \\
Seed shape & Oval & Round & Round \\
Grow type & Straight & Straight & Straight \\
Protein content & $29.9 \%$ & $21.5 \%$ & $23.08 \%$ \\
Fat content & $47.97 \%$ & $43 \%$ & $50 \%$ \\
Amount of seed & $1 / 2 / 3$ & 2 & $1 / 2$ \\
Amount of pod & 29.8 & 20 & 20 \\
Weight of a hundred seed & \pm 31.2 & \pm 47.5 & \pm 37.5 \\
Average result & 2.4 ton/ha & 1.92 ton/ha & 1.7 ton/ha \\
\hline
\end{tabular}

*Source: Balitkabi, 2016 


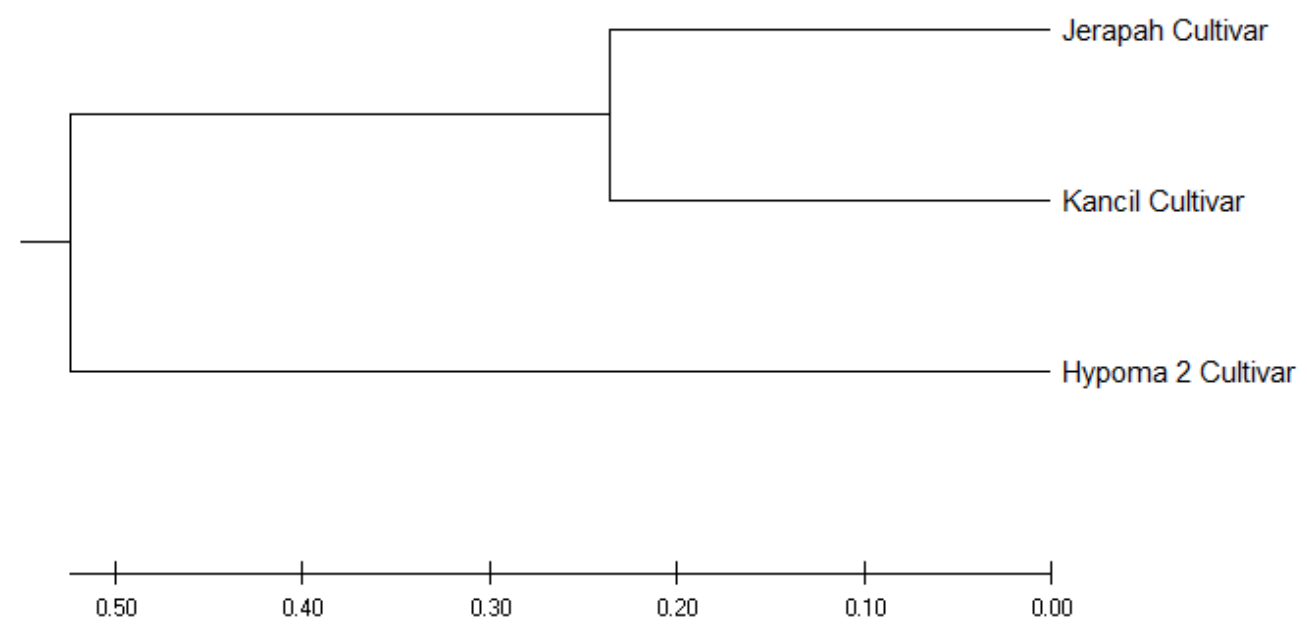

Figure 5. Phenogram of three peanut cultivars

Based on Figure 5. the phenogram shows that Jerapah cultivar has high similarities with Kancil cultivar, while Hypoma 2 is categorized into outgroup. The phenogram shows different results from the RAPD analysis, where the RAPD results show that Hypoma 2 and Kancil cultivars have high similarities based on the amount of monomorphic DNA band that was already amplified. This is in accordance with Barkley et al (2007) that the deficiency of molecular variation in cultivated peanut is somewhat surprising since there is a large range of variation in morphological characters such as seed size, seed coat color, maturation time and disease resistance. According to Agrawal \& Fishben (2006),

\section{REFERENCES}

Agrawal, A. A., \& Fishben, M., 2006. Plant Defense Syndromes. Ecology, 87(7), pp.132-149.

Ardiana, D., 2009. Teknik Isolasi DNA Genom Tanaman Pepaya dan Jeruk dengan Menggunakan Modifikasi Buffer Ctab. Buletin Teknik Pertanian, 14 (1), pp.12-16.

Al-Saghrir, M.G. \& Abdel-Salam, G.A.-S., 2015. Genetic Diversity of Peanut (Arachis hypogea L.) Cultivars as Revealed by RAPD Markers. American Journal of Plant Sciences, 6, pp. 2303-2308.

Barkley, N. A., Robe, D., Roy, N. P., Ming, L. W., Corley, C. H., \& Gary, A. P., 2007. Genetic diversity of cultivated and wild-type peanuts evaluated with M13-tailed SSR markers and sequencing. Genet. Res., Camb., 89, pp. 93-106. significant deviations in the phenotypic clustering could also be caused by convergent adaptation of traits or other processes that generate trait correlations that are independent of association due to phylogenetic history.

\section{CONCLUSION}

It can be concluded that genetic diversity among the three peanut cultivars under study, i.e. Hypoma 2, Kancil, and Jerapah is very low. It is also shown that genetically Hypoma 2 is closer to Kancil, while phenotypically Kancil is closer to Jerapah

Balitkabi, 2016, Deskripsi Varietas Unggul Kacang Tanah 1950 - 2016. [Online] Available at http://balitkabi.litbang.pertanian.go.id/publikasi/ deskripsi-varietas/ [Accessed 30 March 2019]

Holla, K. M. S., Khan, J. A., Sowjanya, M. S., \& Shashidhar., 2014. Monomorphic Molecular Markers Are As Informative As Polymorphic Molecular Markers. Indian J. Genet, 74(4), pp. 596-601.

Kumari, N., \& Thakur, S.K., 2014. Randomly Amplified Polymorphic DNA: A Brief Review. American J. Animal and Veterinary Science, 9(1), pp. 6-13.

Latif, A. A., \& Osman, G., 2017. Comparison of Three Genomic DNA Extraction Methods to Obtain High DNA Quality from Maize. Plant Methods, 13(1), pp. 1-9.

Naipospos, N., Miftahudin., \& Sobir., 2014. Identification of Morphological and Molecular Markers Related to Male Budless Trait on Kepok Banana Mutant. J. Hort, 24(1), pp. 23-31. 
BioEksakta: Jurnal Ilmiah Biologi Unsoed

Volume 1, Nomor 2 (2019): 22-30

Saraswati, I. D., Kuswanto., Damanhuri., \& Sugiharto, A. N., 2017. Analisis Kekerabatan 22 Galur Kacang Bogor (Vigna subterranea L. Verdcourt.) Menggunakan Teknik Rapd (Random Amplified Polymorphic DNA). Jurnal Produksi Tanaman, 5(2), pp. 336-342.
Susanto, M., \& Baskorowati, L., 2018. Pengaruh Genetik dan Lingkungan Terhadap Pertumbuhan Sengon (Falcataria molucanna) Ras Lahan Jawa. Bioeksperimen, 4(2), pp. 35-41 